\title{
INSTITUTIONAL APPROACHES TO THE ORGANIZATION OF COMPLEX SELF-GOVERNING SOCIAL AND ECONOMIC SYSTEMS
}

\author{
Konstantin Zavgorodniy ${ }^{1}$, Vladimir Tkachenko ${ }^{2}$, Sergey Voit ${ }^{3}$ \\ ${ }^{1}$ Research Institute of Economy and Society Development, Alfred Nobel University, Dnipro, Ukraine \\ zkv@yuzhmach.com \\ ORCID: http://orcid.org/0000-0002-7953-3971 \\ ${ }^{2}$ Research Institute of Economy and Society Development, Alfred Nobel University, Dnipro, Ukraine \\ v.a.tkachenko@duan.edu.ua \\ ORCID: http://orcid.org/0000-0002-4919-8658 \\ ${ }^{3}$ Research Institute of Economy and Society Development, Alfred Nobel University, Dnipro, Ukraine \\ ORCID: http://orcid.org/0000-0002-8316-9383
}

ARTICLE INFO

Article history:

Received date 06.02 .2020

Accepted date 15.04.2020

Published date 30.04 .2020

Section:

Socio-economic systems

D O I

$10.21303 / 2313-8416.2020 .001282$

KEYWORDS

efficiency

organizational structures

management systems

market relations

marketable products

quality

industrial relations

\section{ABSTRACT}

The object of research is complex self-regulatory socio-economic systems (such as: enterprise, company, corporation, civil society).

Investigated problem: the problem to be solved consists in substantiating conceptual approaches in the principles of organizing complex self-governing socio-economic systems and substantiating the concepts of their management system.

The main scientific results of the research are the conceptual substantiation of the approaches of both organizing complex self-governing socio-economic systems depending on the objective function of the main activity, and designing management systems to achieve the objective function in market conditions, through the use of existing production and intellectual potentials of the system.

It is shown that in modern conditions of activity, and in the near future, it is forecasting the functional approaches of complex self-governing socio-economic systems based on the use of organizational and production potential and the intellectual potential of workers. At the same time, their organizational structures and operational management systems will be designed, for the most part, taking into account activities in market relations.

The basis of such approaches is the level of organizational and technological production processes that can in a certain way contribute to the achievement of goals and the intelligence of the staff.

The scope of research results can be the design processes of civil societies, corporations by type of activity, enterprises as complex self-governing socio-economic systems.

An innovative technological product is the conceptual approaches of designing economically oriented elements in complex self-governing socio-economic systems.

The scope of the innovative technological product is any industry, line of business.

(C) The Author(s) 2020. This is an open access article under the CC BY license http://creativecommons.org/licenses/by/4.0).

\section{Introduction}

\section{1. The object of research}

The object of research is complex self-governing socio-economic systems.

\section{2. Problem description}

The object of research is complex self-governing socio-economic systems. The difficulties of the transition period, in Ukraine, perhaps somewhere around the middle of its natural term, require the development of a previously unknown strategy for socio-economic development, which should be aimed, first of all, at shaping and the functioning of the institutional system of state and municipal (local) management of the totality of life activities that would stimulate an initiative creative economy In the early 1990s, it was predominantly economic activity that developed predominantly activity (not business, but entrepreneurship) on the basis of economic growth, and structurally innovative transformations of the production complex, the approval of modern civilizational social infrastructure and operational management mechanisms based on social market relations [1]. 
Unfortunately, in our time, the establishment of an institutional system of economic management with social and market relations is impossible due to the absence of a number of theoretical issues and management practices. The key categories of economic theory remain debatable in the present: "institute", "institutes" and "institutional system of society"; coordination of a combination of objective and subjective in the processes of becoming conscious activity); collaborationism or discreteness of the natural development of institutional transformations and so on.

There can be no doubt in such an approach, since the constant of daily economic life is the power itself, which is an aspect in relations between people - the property of one person or a group of people to impose their goals, their vision of a phenomenon. It is economic relations that accumulate the highest degree of power. We mean the power of the owner, the power of management, the power of trade unions, the power of local institutions, management institutions, the power of the state, the power of money, etc.

"Power, E. Toffler noted, is an integral part of production processes, and this is true for all economic systems: capitalist, socialist, and whatever it is" [3].

So the question arises of considering the institutions of entrepreneurship: corporations, industrial enterprises, firms, institutional systems of society as open complex, self-regulating socio-economic systems that meet most of the general theory of classical systems.

Prof. V. Tarasevich in his work, Ecunics: Hypotheses and Experiments (2008) considers that human activity, as a person's purposeful transformation of society and itself, is the result of a natural-historical consistent development of instinctive behavior, which includes not only unconscious, but also subconscious, and mentally conscious, then it is natural to determine the conditions for the interaction of a person with an activity, and it is possible to motivate its behavior. But the basic substantial blocks of human behavior is the purely psychological state of everyone [14]. But V. Velkov in the work "Where is the evolution of mankind" (2003) considers that one should pay attention not only to the psychophysical state of people, but also to the public institutional order, which significantly affects the individual creative activity of people.

A. Grishchenko in the work "Institutional imperialism and its role in the development of economic theory", he believes that what was so lacking for an adequate understanding of economic processes was to recognize the institutional conditions of economic transformations and their influence on the content of transformations [15].

At the current level of development, according to K. Jung, one should speak not only about the genetic inheritance of individual behavior, but also take into account motivational factors of a statistical nature and not of an individual person, but of the conceptual state of collective consciousness.

In our opinion, the determination of the conscious mechanism of the psychophysical state of people, taking into account its social nature of individualism, can be effective in complex self-perpetuating socio-economic systems.

Wit is possible to note that such complex self-regulating socio-economic systems in their composition mainly have social components and, by their nature, are more consistent with bioenergy systems that are able to recognize and restore. And one of the key features of such systems is not just the attraction to their general stability, which is present for classical systems regardless of their nature, but also the ability to play. However, the self-reproduction of such systems in an open and competitive functioning is not just a reflection, but an extension of the complex of parameters.

Moreover, it should be noted that self-reproduction in the most complete sense requires not only quantitative changes in the parameters of such systems, but also their qualitative significance. Moreover, the expanded self-reproduction of such systems due to the quality of parameters, in our opinion, is a priority, since it provides the system with stability not only in space but also in time.

Of great importance for the survival and self-reproduction of socio-economic systems is their potential, which is the specific composition and structure of the variables of the system with certain quantitative and qualitative characteristics that allow to maintain the specified properties of the system, as well as its development in space and time.

\section{3. Suggested solution to the problem}

Without a doubt, also in content, the fact of economic activity is the influence that reproduces power on the economic behavior of people, its content and results. It is possible to give a different assessment of the role, content and degree of influence of power on the economic socio-economic system of society, but it is certain that the behavior of economic entities is, to a day degree, formed 
under the influence of the power system within which they operate, and which includes control and coordination and influence from the existing environment. This, in turn, insists on turning to the theory of organization and the theory of logistics, the development of which creates the prerequisites for the analysis of organizational forms of socio-economic systems based on their synthesis. Indeed, on the one hand, the development of the theory of the resource dependence of the organization allows to talk about the inevitable dependence of the organizational forms of entrepreneurship on the volume and nature of the use of resources, as well as the output, structure of production factors, fixed assets and technologies, material flow systems and their stocks, really affect total potential and size of enterprises. And on the other hand, a comprehensive systematic integrated approach to solving logistics issues requires solving not only physical (determination of reserves in volumes, capacity potential, etc.), but also of an organizational nature. And this is obvious, since various forms of organization of production, its internal and external entrepreneurship determine the methods for reproducing logistics operations, thereby determining the system of restrictions on them [2].

The aim of this research is substantiation of the features of modeling organizational structures of complex self-regulatory socio-economic systems, such as industrial enterprises, corporations, regions, economic systems of the state, based on the use of aggregate organizational and production potential.

It is necessary to investigate:

1. Problems that hinder the development of the national industry of Ukraine and the social sphere of society.

2. To determine the structure of cost-effective elements of complex self-governing socio-economic systems.

3 . To explore the approaches of reproduction and development of the unity of production forces and production relations.

\section{Materials and methods}

A feature of modeling the organizational structure of an economic organization as a socio-economic system is the presence of a subject in it, which acts as an active element in the structure of functions of the management system (for the objects of management: production processes, products, resources; contents of management processes - planning, organization, regulation, control, accounting, at the stages of the preparation and decision-making cycle: marketing or internal audit, adoption and approval, implementation, evaluation, coordination). In connection with the absence of the influence of the active element on the functioning of the institution of an economic organization, the following features can be noted: non-standard parameters, scholastic behavior, uniqueness and unpredictability, ability to change structures without integrity costs, the ability to withstand entropy tendencies to adaptation and focus [3].

It should also be noted that organizational structures exist and change most of all in historical and social contexts. This is a category of extra-long periods - the period of the existence of value-targeted intentions of economic entities, as part of the development of the macroenvironment is reflected in changes of a cultural - historical nature. Unlike classical organizational structures, market structures function within the framework of an already defined strategic orientation of the behavior of economic entities. In other words, the mechanism of market relations has a predominantly economic conjunctive nature. While the organizational component is characterized by the creation of a special internal environment that is the environment of internal constraints and represents the institutionalization of market relations indirectly defined hierarchical structure of the economic organization, which has a set of rules and mechanisms of behavior [4].

The complex relationship between institutions and institutional systems remains the main component, which affects not only the adoption of certain decisions at the level of government and the state as a whole, but, and most importantly, the reactions and strategies for adapting integration processes to changes in the institutional environment. Moreover, the basic institutionalization of the integration process can be imagined in the following form: in order to transform conscious interests in the specific conditions of economic activity.

Economic entities create institutions that serve as one of the ways of aggregating and articulating interests, obtaining political support and the possibility of influencing economic policy. On the other hand, the institutions themselves and institutions affect the nature of activities and awareness 
of interests of economic entities. With this approach, interests are realized in economic policy and determine strategies for economic development [5].

At the same time, it should be noted that in the process of development of integration, their functions may change, based on the need to perform additional tasks related to integration. So, the government can create structures that deal with, inter alia, integration issues; multinational companies may appoint special representatives to negotiate specific projects within integration associations. At the same time, integration institutions are a specific way of mediating the interests of integration entities: integration entities interact among themselves in order to create supranational companies, organizations and implement them to fulfill the relevant powers [6].

This is the meaning of new approaches to designing organizational structures of complex self-regulating socio-economic systems.

The classical theory of management requires the purposeful formation of the composition and structure of the constituent elements of socio-economic systems, which create the potential of the system: the formation of control subsystems, the formation of the necessary quality elements of the system, the provision of existing elements of the organizational structure with new properties, the establishment and optimization of the relationship between the elements, the removal of unnecessary elements from system.

Management of the organizational structure of the system, as its functioning potential, occurs due to classical approaches: planning, organization, control, motivation, and the external environment.

It is worth noting that in the present, it takes on special importance to control the external component of the potential of the system, which is a rather complex process, on which there is a need to dwell better.

The classical theory of management suggests that the socio-economic system can't manage its external environment [7]. It can respond to external influences and adapt, where the external environment also enters, as one of the components of the density of open systems, then there is a need to manage this component if an expensive complex self-regulating socio-economic system, such as an enterprise, company, corporation, etc. intends to function effectively, then it must purposefully manage, or shape its external environment. For this, first of all, one should change its attitude, its philosophy of understanding the processes taking place. And it is the finished products that are ready, their cost is the most influential lever to control the external environment.

Therefore, it is natural that in managing the external environment, as a component of the aggregate potential of complex self-regulating socio-economic systems, the main emphasis will be placed on indirect methods of influence. But a deliberate impact on the external environment and due to other components, such as specific relationships with suppliers, etc., in order to provide the system with the most appropriate characteristics, is a prerequisite for the effective management of its potential [8].

It should also be noted that one of the most important conditions for managing the potential of any system is not the presence of its various elements, but their ability to reproduce new elements in a short time and at the lowest cost, bring the relationships between them and ensure efficient functioning.

So, the potential of any organizational structure of socio-economic systems should be able to timely and accurately reproduce the necessary elements that formed the strategic potential of a brand, technological base, scientific development, corporate culture, etc., which is a conditional constant because it can't be reproduced in the short term. But the low level of this component very negatively occurs in the ongoing activities and leads to the cost of operating potential. The inefficiency of the organization's strategic potential is possible to compensate for the operational managerial potential: financial resources, labor resources, abandonment of part of the profit, etc. But such compensation will be inadequate for external and internal conditions, since the costs of the operational potential will grow exponentially.

There are also components of organizational structures that should be more specifically formulated to solve a certain range of tasks, as necessary. These are the components of the operational potential, which form such variables as resources (except labor), equipment, buildings and structures, as well as pricing, which make up the costly mechanism [9].

Thus, the general mechanism for managing the organizational elements that make up the potential of complex self-regulating socio-economic systems is determined as follows:

- any organization, as a complex open system, daily uses strategic potential and its components, together with the influence of the external environment; 
- on this basis, a system of goals, aim and mission is formed;

- after that, the organizational structure of the operational potential is formed, which is fully used in the process of implementing the goals system.

At the same time, efficiency should be considered as a potential management mechanism, which allows forming an adequate operational potential on the basis of strategic potential, which, in turn, is able to solve the current and most promising tasks of activity and turn them into strategic potential.

Since the organizational structure of any system is a set of interconnected elements, while the overall performance of the system is more influenced not so much by the quality indicators of the organizational elements themselves as by the quality of the links between these elements, another important aspect follows in the management of such systems, their potential, which allows the total potential of the organizational structure should be submitted as follows:

- element-wise potential, which is a combination of individual elements of the external and internal environment (material, financial resources, equipment, technological base, suppliers, consumers, etc.);

- potential of relations between individual elements (management system, goals and objectives system, communication system, knowledge, experience in making managerial decisions, etc.).

As it is possible to see, the potential of connections allows to form functional processes from individual elements of the system that form the output flow processes (finished products), input flow processes (factors of production, activity), as well as the processes of transformation of incoming flow processes into output flow processes are formed adequately .

The systematic approach will not be complete if do not dwell on another important task - these are the criteria for measuring the potential of the organizational structure. In other words, to design an effective management system, evaluation criteria are needed, they would inform the organization's management about the state of the potential of the organizational structure and the organization as a whole and its trends.

The complexity of this problem lies in the fact that the concept of potential itself has an amorphous state, rather complex, includes several components of uncertain quality. Moreover, it should also be noted that these components are so different from each other in nature, that is, in their composition and structure they have variables that function and develop according to fundamentally different laws and do not have a common denominator [12].

As for the internal potential of the system, its essence lies in assessing the quality of all production assets and the total costs of the operation of the operating management system. The basis of this approach is the assertion that it is necessary to build up those assets that really allow creating added value (fixed production assets, labor resources, etc.). Other assets necessary for the normal functioning of the system, they do not help create added value (raw materials, semi-finished products, work in progress, etc.). They must have minimal contributions, their composition and structure must be highly liquid, and the period of their transformation into products is the minimum possible.

And yet, using this approach, through some integrated indicator, it is possible to assess the overall internal potential of a system. But it still does not allow to assess the level of the internal element-wise and internal whole potential of the connections between the elements, as well as determine the cause-effect relationships.

As for the potential of the external environment in which the system operates: corporate image, social meaning, brand image, degree of customer loyalty, stability in relations with suppliers, etc. it can only be estimated indirectly. The estimate obtained in this way does not have the ability to be integrated either at the methodological or mathematical level with the assessment of the internal potential of the system. So practically it is not possible to get a general assessment of the total potential.

The urgency is the need to develop such a methodology both at a practical level and theoretically.

So in the work it is taken as a rule: the economic policy of the state in the transition period (period of transformation) should be aimed at solving a two-pronged fundamental problem:

- firstly, the creation of economic and legal conditions (institutional basis) of market relations;

- secondly, this is the development of the business environment (rinu players), social partnership as an institution of market relations, based on self-regulatory socio-economic systems.

But, to develop a scientifically based concept of institutional transformations, as the basis for further organizational development, a categorical certainty of the fundamental postulates of the the- 
oretical base and methodological approaches to reforming both the development mechanism and its ideology is necessary. The creation of a system of social partnership in a classic institutional setting has a prerequisite for the legislative existence of certain subjects of social and labor (production) relations, an organizationally created mechanism and practical procedures (organizational and technological processes), coordination of optimal interests in the economic and social spheres of society [11]. Such an approach becomes common in the process of transformation of economic, political and social relations in the current state of the scientific and technological revolution and its impressive social consequences for both individual enterprises, countries, and for all mankind. The cardinal issues of the physical and spiritual existence of man and of humanity as a whole on planet Earth, the problem of global contradictions, the organization of labor, distribution of objects - objectification and alienation of labor, the objectivity of material and spiritual products and concessions facing humanity are especially relevant and acute in organizational and structural terms.

From the point of view of philosophical, epistemological and spiritual - social approaches, social partnership, as an institution of market relations, is a set of processes, the initial methodological principle of which is a natural opportunity, in which a person not only reflects the real world, but also creates it, building in the process of labor not only the material values that form the basis of the economic system, but also, revealing its intellectual potential, at the same time it builds on the learned and technical "second nature "rather than objectified spirit and material values and society and constitute the institutional basis of market relations. It is expedient, ideally directed to uncover creative intellectual potential and is the work itself, its essence, that main element, without which the existence of a social formation is impossible.

Based on the historical-philosophical and conceptual-social analysis of the problems of institutional management of the economy, with a look at the main trends in the development of social formations and their social production, it represents the main foundations of the economic system of society, taking into account the main trends in the development of scientific and technological progress, it becomes possible to determine the basic principles and signs of reproduction of the institutional management system [15]:

- firstly, institutional management is a reflection of the relationship of a person - a subject to the internal and external world as an object - answers a set of questions: what is the place and role of each person in the processes of reproduction; or, in other words, can and can't do what a person and society as a whole; what is necessary for the disclosure of individual and social intellectual potential; on what principles and by what forms and methods is production reconstructed, what system reflects "expedient activity, means of labor and objects of labor";

- secondly, the institutional management of the economy as a phenomenon arises and functions only in the process of an active creative relationship of a person in the process of reproducing its intellectual potential to nature and to society in general principles of the existence of a social formation. That is, institutional management is possible only in the process of labor, in the process of social production of ideas and things aimed at satisfying various social and personal needs and interests;

- thirdly, the institutional management of the economy is a mechanism of creative, creative visual activity, consists in the dialectical interaction of the processes of distribution, idealization, objectification, and alienation from a person of material and spiritual products of its activity, reproduce both positive and negative socio-economic consequences in the process development of social formation, often become social and human global problems, which often unpredictable.

Institutional management, as a social phenomenon, is, above all, indifferent to different layers, layers, classes and groups in a social formation. However, social communities themselves have different needs and interests, use products or the results of their activities in different ways for the good or evil of themselves and society. With various uses of the achievements of spiritual and material culture, at different levels of the intellectual potential of institutes and institutes, the socio-economic consequences of a positive or negative plan arise [10].

The crisis in industry, in the financial sector is the consequences of the crisis in the institutional management system that arose and develops in the process of transformation of society associated with the transition of our state to market economic relations, the development of a new system of national economy. The fall in GDP is often associated with the liberalization of prices and foreign relations, serious miscalculations in the implementation of economic reforms, and inconsistency in the implementation of structurally innovative industrial policies, significantly lagging behind policies in 
the field of privatization of state property and shifts in the financial and banking system. But all this is nothing but a consequence of the neutralization of one system of institutional management of the economy and the restructuring of new institutions and management institutions in the new economic conditions. The state refused to fulfill the function of administrative redistribution of both material assets and working capital for capital formation, which is explained by the insufficient state revenues to ensure the costs of economic activity. Under such conditions, the inertia in ensuring innovative processes has sharply increased, the loss of the possibility of obtaining any capital from state-owned centralized funds, the inability to provide adequate capital market management for domestic enterprises, as well as their difficult financial and economic situation, have led to negative dynamics in innovation and investment processes production update.

All this led to the deployment of the inflationary spiral and a sharp reduction in solvent demand. Inflation not only devalued the savings of the population, which could become an important source of capital formation, but also devalued the accumulation of capital of enterprises in the form of reserve and depreciation funds, the enterprise development fund, which led to the general financial crisis [13]. In fact, that part of the equity capital of enterprises and, naturally, of the state as a whole, was lost, which could rush to advance to new innovative projects, technological and technical updating of production. With this approach, a fall in solvent demand for products from related industries and industries, depending on machine building and machine tool industry, was provoked. This also led, to a large extent, to the "washing out" of working capital of enterprises. The non-payment crisis, which covered a significant part of the industrial complex, led to a significant increase in their receivables and payables. Thus, having collapsed the system of institutional management, the state self-consciously took away the function of redistributing funds for the formation of equity, which provided an opportunity for non-state enterprises, and their share increased significantly, also to abandon the accumulation of capital to update their own production. Thus, the state has lost the possibility of increasing state revenues to ensure the costs of transformational measures of economic activity.

Today, the most developed countries of the world are experiencing the transformation of an industrial society into an information society, which requires the development of an economic system based on information and innovation processes in the investment sector. The most important feature of such an economy is the latest technology with scientific and practical justification, which becomes the main factor in modern production. But we could not even create market relations. They did not create because they did not create. The inertia in ensuring innovative reproduction processes, the loss of opportunities to obtain preferential capital from centralized state funds, the inability to ensure adequate market conditions for managing capital formation at domestic enterprises and in the state as a whole, as well as their difficult financial and economic situation, determine the negative dynamics of innovation and investment processes in the country's industrial sector, to invoke the collective transition to a new social formation of obligation An essential condition for the survival of the individual.

Therefore, if we want to survive the upcoming cataclysms that naturally accompany the transition process, then we just need to "wake up" as many people as we can acquaintances and strangers, of various professions and activities: thinkers and politicians, artists and businessmen, military and civilian, increase population density, and constitute a critical mass of society.

The transition period from one social formation to another is a kind of evolutionary selection. And in crisis situations, evolutionary selection occurs both at the level of individuals and at the level of human communities. Surviving the planetary crisis is not just healthy people, but healthy nations, the most moral, organized, technologically equipped, with high social intellectual potential.

Explosions of emotions scare. Social apathy, which often spontaneously turns into aggression, sometimes leads to despair. But, fortunately, it's not these grimaces of the crisis that determine the future face of society, but rather the complicated, intense intellectual work, crystallizing the attitudes of their future activities. And if we can openly talk about adequate awareness of the social crisis, then this will already be a step towards overcoming crisis phenomena in the public consciousness itself.

The main thing that determines its content at present is structural shifts in the value orientations of people. Since the beginning of the 1990s, society has come to understand the hopelessness of the socio-economic formation that existed and the need to develop a constructive program to overcome the crisis.

Affirmation of the value attitude to humanity as a whole is irreversible. The priority of universal values over class values is felt more and more. It is possible to say about fairly stable national 
values in the public mind. The idea of mercy paves its way. In general, a person becomes a center of value orientations. An attempt to realize this new imagination is evident in disputes regarding subjects of ownership, law, etc. And the democratic electoral system, putting individuals in the circle of public discussions, gradually filters out those human qualities that become socially significant values.

Of course, in general, it is too early to talk about a new system of value orientations. The most vulnerable here is a change in ideological values, which in the public consciousness are primarily associated with the existing social system and its main attributes: state power, the economy, and spiritual life.

The value attitudes of the socio-political forces that are in power represent the "top" of the hierarchy of ideological values, and the corresponding attitudes of the opposition occupy a subordinate position. With a change in the concrete historical situation, the roles of existing objects change, new social groups appear that are represented in the public consciousness through their value priorities.

The orientation of public consciousness as a whole is also changing, which is confirmed by the ideological and political situation typical of many regions of our country with some common features that must be taken into account when developing an action program that is adequate to the current state of public consciousness.

Today, our country has faced the task of a comprehensive and phased updating, transition to a state of a new social formation. For this, it is necessary to transform, first of all, property relations in the classical understanding of its content. It is necessary that public property be expressed in one form or another of ownership, direct disposal and use of each transferred collective or its member a share of this property in the interests of the individual and the whole society.

It should be remembered that the birth of a new social formation and its economic system is both an endo and an exogenous process. For not only the specifics of the withering away of the past formation, but also the global atmosphere gives rise to the genesis of production relations in transition systems. One of the most severe forms of this duality is the struggle of comprador and state directions (aspirations) in the formation of a socio-economic system. At the same time, despite the presence of some objectively conditional (also endo, and exogenous) restrictions, a choice of the future is possible in the transition period, due to the many forms that the process of expansion of dominant production relations takes on. This is a wide range of models on the country's development scale, is changing its social formation, and with it the economic system of management, taking into account the potential for regulation, socialization of the economy and democratization of society.

Of course, to analyze the transition economy without taking into account and identifying specific features and patterns, for example, such as the global (in space) and general civilization (in time) process of socialization of the economy and humanization of society is the highest intensity in our present, at least, incorrect.

And, most importantly, we must realize this with our minds. Although, to be honest, awareness is a dead end from which there is no way out.

Sadly, it is precisely such general purpose, recommendatory and methodological constructions of further development, although they have certain conventions and shortcomings.

Indeed, humanity enters a completely new stage in its development, when only the collective mind (and do not be afraid of it), collective will and collective purposeful actions give a chance for the prospect of further progress.

The problem of a general vision of the world, its development, the problem of an integral overall picture of the Universe, in which general knowledge would not only be consistent with each other, but also allow a person to see, in the mirror, itself, its place in versatility and multicolor facts, processes, events.

Hence the urgent need for a common, synchronous study of nature and society.

On the agenda are the definitions of fundamental truths in understanding the prospects for nature and humanity, which make up unity and integrity, their development and the future in general.

It is necessary to ensure the optimal coordination of social development with the functioning of the Universe, when human activity is organically included in the algorithm of vital functions of all nature, without disturbing, but, on the contrary, promoting the ordering and vital activity of the latter.

Life is always inherently deeply dialectical: success is just the other side of defeat, and vice versa.

It has always been so and, apparently, it will be so. 
But this contradiction should not become the basis for "lowering hands", since a layer of scientific knowledge arises on its basis, determines human behavior, makes reasonable and rational restrictions and recommendations necessary to ensure the further development of civilization.

\section{Research results}

The theory of economic growth and transformation into new relationships, as well as the methodology of their analysis, do not allow the separation of rates from their sources and the quality of the processes themselves. That is why, before considering the role of public administration of the processes of transformation to market relations, it should be determined by what factors growth can be achieved. It should be borne in mind that the pace reflects only relative indicators of economic growth, while in assessing the quality of such growth, one can't but take into account the processes of increasing the weight of each percent, as well as the composition and structure of its filling, product quality, its technical and consumer properties. At the same time, the national structure of the economic complex and the composition and ratio between the final and intermediate products are essential.

So, the growth rate, the processes of their formation is not a determining phenomenon at all, as such, it is the result of the interaction of a number of factors and conditions, which ultimately determine the dynamics of economic growth.

It should also be noted that both in practice and in theoretical slowdown of economic growth in the short term, it is permissible if a structural and investment regrouping occurs in the economic system, or maneuvering with the aim of future growth is reproduced. Unfortunately, in our case, neither one nor the other happened. In addition, practice shows that even minor changes in economic growth in the direction of falling in the long-term interval are not only being allowed, but it must also be remembered that this is very dangerous. After all, such actions reflect nothing more than a weakening of the economic basis for expanded recovery, since the decline in pace from year to year can't be compensated for by increasing the weight of each percent, leading to an absolute decrease in the growth of national income.

\section{Discussion of the results}

The research results were discussed at the Scientific Council of the International Academy of Bioenergy Technologies and at the International Scientific-Industrial Conference " 25 years of knowledge of the spatial-wave substance of worldview ideas" and received a positive assessment. And they were also tested at the State Enterprise "Production Association Yuzhny Machine-Building plant named after A. M. Makarov" (YUZHMASH) contract No. 151/816 of November 11, 2017).

Research continues in the direction of designing "Theories of designing complex self-governing socio-economic systems".

\section{Conclusions}

1. Thus, the collapse of the institutional system of managing the domestic economy has created problems that impede the development of domestic industry, the agro-industrial complex, the communal environment and the social sphere as a whole, thereby creating a vicious circle of decline. Outdated technologies and a high degree of depreciation of production equipment negatively affect the competitiveness of products, which leads to a decrease in effective demand for them. And the crisis state of the political-power system devalues the value of the state in the international sense. The solution of certain problems is possible not only and not so much by updating the technological base of society, represents the most important aspect of restoration and development, but from the restructuring of production capacities and the structure of the economy as a whole, which is possible only if an institutional management system and additional capital are attracted in the form investments at all levels: own enterprise, regardless of form of ownership, state priority restoration and foreign investment national priorities.

2. Naturally, each of the subsystems structurally has its own, unique to it, rare set of elements packaged in a unique mechanism of functioning. Socially oriented elements are groups of people and individuals: family, a group of people in production, groups of enterprises, firms, associations, a region, a region, an industry, a state, with the same system as factors in creating results of activities (marketable products, materials, services) and users of the results of their activities. Business entities act as economically oriented elements in complex socio-economic systems: enterprises of various 
organizational and legal forms and methods, entrepreneurs of various purposes, who, on the one hand, are consumers of socially oriented elements in the form of labor resources and entrepreneurial abilities of intellectual potential, and on the other hand, producers of defined goods.

As for the political oriented elements, they act as: a system of law, a legislative base and state authorities, which, on the one hand, perform the functions of planning the growth and development of both the socio-economic system and the environment in which it operates, improving its organizational structure and management and control system, and on the other hand, is a social order of both defined goods and specific producers.

So, a complex self-regulating socio-economic system should be considered as a complex system of systems, conditionally considering it a closed system. The complexity of such systems is that, on the one hand, they organizationally consist of many systems according to their functional necessity, and on the other, each of them is a set of systems of a more or less different order in the hierarchy.

3. Industrial relations today are a combination of technological, technical and economic relations between members of a social formation, which are formed in the production process depending on its nature and degree and property relations, determining the technological base and socio-economic structure of society. These relations, which should be considered not only as interactions between people, are the main link (or rather a mechanism) of relations in the socio-economic system, but also as the corresponding interactions between the social formation and Nature. The materialization of these interactions forms a new concept of the technological base of society (its production forces) and provides the dynamism of the development of intellectual potential, which in turn determines the nature of the technological basis of production through the consistent implementation of knowledge and changes in production relations. As a result, it is precisely the changes in the technological base of society that motivate changes in the socio-economic system of one or another social formation based on the technological method of production as a dynamic system of technological relations.

Thus, we get the opportunity to design the concept of regulatory parameters for the development of models of socio-political and socio-economic systems, which can simultaneously take into account the production potential of society and industrial relations of people, the technological base and socio-political and socio-economic foundations, environmental subjective and subjective factors development of socio-public formation, an integral part of which is the moral and spiritual imperative.

\section{References}

[1] Polokhalo, V. I. (Ed.) 2009). Stratehiia innovatsiinoho rozvytku Ukrainy na 2010-2020 roky v umovakh hlobalizatsii vyklykiv. Materialy Parlamentskykh slukhan u VR Ukrainy, 362.

[2] Toffler, Z. (2001). Metamorfozy vlasti. Moscow: OOO «Izdatelstvo AST», 669.

[3] Tarasevich, V. N. (2008). Ekunika: gipotezy i opyty. Moscow: TEIS, 565.

[4] Gritsenko, A. A. (2008). Institutsionalnii imperializm i ego rol v razvitii ekonomicheskoi teorii. Naukovi pratsi DonNTU. Seriia: ekonomichna, 34, 46-51.

[5] Pevzner, Ia. A. (2001). Vvedenie v ekonomicheskuiu teoriiu sotsial-demokratizma. Moscow: Editornaia URSS, 208.

[6] Liashenko, V. I. (2006). Regulirovanie razvitiia ekonomicheskikh sistem: teoriia, rezhimy, instituty. Donetsk: DonNTU, 668.

[7] Chorna, L. O. (2008). Rezultatyvna stratehiia dosiahnennia investytsiinoi pryvablyvosti pidpryiemstva. Investytsii: praktyka ta dosvid, 24, 4-6.

[8] Tkachenko, V. A., Kholod, V. I., Klochko, V. M. et. al.; Tkachenko, V. A. (Ed.) (2013). Teoriia proektuvannia velykykh samokerovanykh sotsialno-ekonomichnykh system. Vol. 3: Systemnist va poli nevyznachenosti u skladnykh samorehuliuiuchykh sotsialno-ekonomichnykh systemakh. Dnipropetrovsk: Monolyt, 244.

[9] Carvalho, J. P., Tom, A. B. (1999). Rule Based Fuzzy Cognitive Maps: Fuzzy Causal Relations. Computational Intelligencefor Modelling, Controland Automation, 276-282.

[10] Goldberg, A. S. (1998). Introductory Econometrics. Harvard University Press, 241.

[11] Gregory, J. R., Wiechmann, J. (1997). Leveraging The Corporate Brand. New York: McGraw-Hill, 256.

[12] Abchuk, V. A. (2000). Ekonomiko-matematicheskie metody. Elementarnaia matematika i logika. Metody issledovaniia operatsii. Moscow: Soiuz, 320.

[13] Shuliar, R. V., Holovchak, Kh. Yu. (2012). Osoblyvosti roboty system menedzhmentu pidpryiemstva v umovakh neobkhidnosti zdiisnennia orhanizatsiinykh zmin. Naukovyi visnyk natsionalnoho lisotekhnichnoho universytetu Ukrainy, 22 (2), $228-303$.

[14] Shapkin, A. S. (2003). Ekonomicheskie i finansovye riski. Otsenka, upravlenie, portfel investitsii. Moscow: Dashkov i Ko, 544.

[15] Akkoff, R. (2002). O menedzhmente. Saint Petersburg: ID Piter, 448. 